\title{
REJOINDER TO WISNIEWSKI ON EVICTIONISM, ROUND FOUR
}

\section{EVIKCIONIZAM - REPLIKA VIŠNJEVSKOM, ČETVRTA RUNDA}

\author{
Walter E. Block \\ Harold E. Wirth Eminent Scholar Endowed Chair and Professor of Economics, \\ Joseph A. Butt, S. J. College of Business, Loyola University New Orleans, LA
}

(C) MESTE NGO

JEL category: K19

\begin{abstract}
Evictionism means that a pregnant woman has the right to evict, but not kill, a fetus entirely at her discretion. Assume that the baby is viable outside the womb only during the last trimester. Then, evictionism implies the same result for the unwanted fetus in the first six months as pro-choice. That is, the mother may evict the fetus, not kill it, but the fetus will die. But for the last three months, the implications are the same as pro-life. That is, the mother may still evict the fetus, not kill it (no partial birth abortions would be allowed), but now the fetus can survive outside the womb. Wisniewski, a prolifer, and I have been battling over this concept for three iterations. Both of us are libertarians and hence start with the same basic premises. Nevertheless, we have not yet been able to resolve our differences, although we have both ranged widely and thoroughly throughout this challenging issue. The essay that follows is my most recent attempt to defend evictionism against his pro-life criticisms.
\end{abstract}

Keywords: eviction; abortion; pro-life; pro-choice

\section{Apstrakt}

Evikcionizam znači da trudnica ima pravo da iseli, ali ne da ubije, fetus u potpunosti prema svom nahođenju. Pretpostavimo da je beba održiva izvan materice samo tokom poslednjeg tromesečja. Tada, evikcionizam podrazumeva isti rezultat za neželjeni fetus u prvih šest meseci kao i "pro-choice" (pravo na izbor). To jest, majka može da izbaci fetus, da ge ne ubije, ali fetus će umreti. Ali za poslednja tri meseca, implikacije su iste kao i "pro life" (pravo na život). U tom slučaju, majka može i dalje da izbaci fetus, ne ubije ga, ali sada fetus može da preživi van materice. Višnjevski, pristalica ideje "pro-life", i ja smo se sporili oko ovog koncepta triput. Mi smo obojica libertarijanci i stoga počeli sa istim osnovnim postavkama. Ipak, još uvek nismo u stanju da rešimo naše razlike, iako smo obojica vrlo široko i temeljno

The address of the author:

Walter E. Block

䤵”'wblock@loyno.edu razmatrali ovo izazovno pitanje. Esej koji sledi je moj najnoviji pokušaj da odbranim evikcionizam od njegovih pro-life kritika.

Ključne reči: iseljenje, abortus, pro-life, pro-choice 


\section{RESEARCH HIGHLIGHTS}

Research Highlights:

- Purpose: To shed light on the controversy between pro-life and pro-choice viewpoints

- Design: Implications from private property rights are deduced via verbal logic

- Findings: Neither pro-life nor pro-choice viewpoints are correct

- Practical implications: public policy should be based upon an alternative perspective

- Social implications: justice would be promoted; human lives would be saved

- Originality/value: this paper introduces an alternative to both pro-life and pro-choice viewpoints

It is a joy and a pleasure to be engaged in this interchange with Wisniewski. ${ }^{1}$ Part of the reason is that it is almost not really a debate at all. At least it is not one where we are only trying to score points against each other (although in my opinion both of us sometimes do that; none of us are perfect). Rather it at least seems to me to be an honest attempt on both our parts to get at the truth of a very complex issue that has beguiled and eluded thousands of scholars and theorists. They have long looked at the pro-life versus pro-choice issue without shedding much light on this challenge, although quite a bit of heat. But, if I can continue to speak both for me and my "debating" partner, we have one advantage they do not enjoy: we are both libertarians. I am in full and enthusiastic agreement with Wisniewski $(2013,153)^{2}$ when he says "we both derived our respective arguments from the same set of principles - the libertarian axioms of selfownership and non-aggression." I also cannot offer him (153) stronger support when he maintains that our exchanges "provide... yet another illustration of the fact that, despite being clearly distinct from other political and moral philosophies, libertarianism is a complex and internally heterogeneous body of thought, riddled with many thorny and contentious issues."
I fully agree with Wisniewski's (154) assessment that the benefits of our exchanges are by no means limited to abortion; that they also constitute "a valuable discussion of some of the related complexities of libertarian philosophy."

Before getting into the substantive issues where we again begin bashing each other's theories, but in a friendly way, let me throw one more accolade at this young man; while we do not at all agree on evictionism, I am delighted when I think that the next generation of libertarian theoreticians is in good hands with the likes of this author. I know that I have been in a "fight" with him after our several interchanges, and he has come up with numerous libertarian insights in the course of it that have forced me to dig deeper and deeper in defense of evictionism. Moreover, he has always exhibited that spirit of the two of us working in partnership to get clearer on our philosophy, something I greatly admire and also attempt to engage in.

Before responding to Wisniewski's latest contribution to our ongoing debate, let me summarize what has come before, for the reader who has not seen the previous iterations.

I had been publishing on the evictionist doctrine for many years (Block, 1977, 1978, 2001, 2004A, 2008, Block and Whitehead, 2005). My debate with Wisniewski started with his publication 2010A, where he criticized evictionism on the ground that "if one voluntarily initiates the causal chain which leads to someone else ending up on his property, the latter person cannot be considered a trespasser. Furthermore, in the light of the above observation, any direct effects resulting from that person's eviction should be considered the responsibility of the property's owner." In response I (Block, 2010) argued "... there is a storm. It is a deadly one. If you stay outside, you will die. I invite you inside my house. I thus make you a "trespasser." A month goes by. A year goes by. Ten years goes by. The storm persists. If ever I disinvite you, if ever I ask you to leave my abode (I have been feeding and clothing you all this time), I will be guilty of murder, according to Wisniewski, because I have made you "a 'trespasser' in the first place." Suppose I

\footnotetext{
1 See on this Wisniewski, 2010A, 2010B, 2011;

${ }^{2}$ All quotes from Wisniewski are from this one 2010, 2011A, 2011B; Block, 2010, 2011A, 2011B paper.
} 
board, house and feed you for five years, whereupon I turn you out into the storm, and to your death. I am a murderer. I get no credit for keeping you alive for five years, according to Wisniewski." That was the end of what I call round one.

Round two opened up with Wisniewski (2010B). Here, he maintains, "... abortion (i.e., lethal eviction) involves the amount of physical harm done to the fetus that is grossly disproportionate to the amount of physical harm that the fetus can possibly do to the mother." I replied (Block, 2011A) that "In Wisniewski's view, allowing the mother to evict the fetus when this results in the death of the latter "is tantamount precisely to blowing the trespasser away with a bazooka when there exists no other ways of removing him from one's lawn." Well, yes, it is. Where Wisniewski and I part company is that he thinks that under these circumstances it would not be justified for the property owner to kill the trespasser, while I maintain that it would. ${ }^{3}$ After all, if we are to accurately employ the libertarian legal nostrum, "gentlest manner possible consistent with stopping the crime," then that trespasser must be stopped. ${ }^{4}$ And, I contend, Wisniewski is lead into this erroneous interpretation of libertarian law because of his confusion between proper punishment after the fact, and, proper defense, during the time the crime is being perpetrated.

Wisniewski (2011) addressed in round three "the distinction between proper ex post punishment and proper ex ante defense, the question of whether my causal analyses of trespass imply a commitment to positive obligations, Rothbard's distinction between contracts and promises, the supposed irrelevance of the principle of pacta sunt servanda in the context of abortion, and the extent to which custom can qualify the ambit of applicability of the non-aggression principle." My (Block, 2011B) contribution to this round is to distinguish between trespassing on someone's land, and trespassing inside of their bodies, and

3 Wisniewski here makes a very heroic assumption. One wonders why the property owner did not put up a sign to the effect that "trespass is forbidden," or "I will shoot trespassers," or some such. claim that the latter is a far more serious rights violation than the former.

In round four, my debating partner (Wisniewski, 2013) takes the position that abstaining from lethal evictions of fetuses conceived as a result of rape is a libertarian duty, but only an imperfect one. I will not further explain this concession of his, since it is the burden of the present paper, my contribution to round four, to explicate and criticize this perspective. With this introduction, I am now ready to take up the cudgels in defense of evictionism.

\section{EVICTIONISM VS. THE PRO- CHOICE AND PRO-LIFE POSITIONS}

Let me now undertake to defend evictionism against both the pro-choice and pro-life positions.

\section{No qualification}

I regard Wisniewski's position as a straight out critique of evictionism from the pro-life position, not a "qualified" (153) one as he maintains. I do not see any of these "qualifications" to which he alludes. I perceive no difference between his critique of evictionism and one that could have been launched by any highly intelligent, creative and forceful libertarian of the pro-life persuasion.

\section{Morality}

I do not maintain, as Wisniewski (153, emphasis added) asserts, that I "consistently argue ... for (the) view that the mother is morally allowed to expel the fetus from her womb provided that no non-lethal methods of its eviction are available." Rather, in sharp distinction, it is my position that "that the mother is legally allowed to expel the fetus from her womb provided that no non-lethal methods of its eviction are available." I was not discussing morality or ethics. But, as long as there is a focus on this, my own moral principles, such as they are, are entirely on the pro-life side (as are Wisniewski's, as I understand them). I think it is

${ }^{4}$ If that is indeed the wish of the property owner. Wisniewski might take some solace from the fact that his neighbors might boycott him, unless the trespasser was shown to be dangerous. 
highly immoral for a woman not to bring her baby to term, provided her life is not thereby put in grave danger. Life is precious; human life infinitely more so. To evict a viable fetus is a moral horror, in my view. However, as far as I am concerned, my dispute with Wisniewski has nothing at all to do with ethics. Rather, it concerns what the law should assert on this issue. Given libertarianism and its emphasis on private property rights, and, positing that the pregnant woman, and no one else, is the owner of her body, then it follows ineluctably, Wisniewski and other pro-lifers to the contrary notwithstanding, that she may evict any trespassers on it, or, rather, inside of it. Period. To deny this is to reject the claim that either she owns her womb, a manifest error, ${ }^{5}$ or that ownership does not convey the right to determine what people or entities may properly reside within it, an essential element of libertarianism.

\section{Pure Austrian Snow Trees. ${ }^{6}$}

I draw a sharp distinction between what a target may properly do to defend himself from an imminent or ongoing attack (pretty much anything within reason necessary to safeguard himself assuming he confines his reactive violence to the attacker) and what punishment may be inflicted on the perpetrator afterwards. As to the latter, I maintain that proportional punishment ${ }^{7}$ is the only response compatible with the libertarian philosophy. In contrast, states Wisniewski (154), “... an act of self-defense (even one resulting in the trespasser's death) does not violate the principle of proportionality. Thus, he zigs where I zag. ${ }^{8} \mathrm{~A}$ trespasser is an invader. From my perspective, then, it matters not one whit whether or not this act of self-defense (moving the trespasser out of or away from the premises) is proportional or not. It certainly need not be. In any

\footnotetext{
${ }^{5}$ Who else could possibly be the legitimate owner of her body apart from herself?

${ }^{6}$ Don't ask.

7 In the view of Rothbard (1998, p. 88, ft. 6): "It should be evident that our theory of proportional punishment-that people may be punished by losing their rights to the extent that they have invaded the rights of others-is frankly a retributive theory of punishment, a 'tooth (or two teeth) for a tooth' theory. Retribution is in bad
}

case, proportionality only applies to a legal punishment, after the crime, not to legitimate defensive actions during the time it is being carried out.

Wisniewski (154-155) then asks us to recognize "that $Y$ can justifiably deprive $X$ of his life only if $X$ threatens Y's life (as in the situation where carrying the fetus to term threatens the mother's life). Certainly, if the trespasser threatens the owner's very life under libertarian law she would be justified in removing it, and of course need not worry about proportionality or any other such thing in so doing. But I go further: the target may remove a trespasser with "extreme prejudice" as they say in the hit man movies for far less than an imminent threat of death, if that is the only way to defend oneself. For example, suppose it a given that $A$ will (with no justification at all) inflict a severe beating upon $B$, and that the only way $B$ can stop this occurrence is by killing A. According to our author, if I understand him correctly, it would be impermissible for $B$ to kill $A$ in self-defense, because B's very life was not in question. This does not at all sound like libertarian law to me. Let me put this in other words. I regard myself as a moderate on this question. There are some libertarians who say that the criminal has violated the civilized order. He is an outlaw. Therefore, anything, anything at all may be done to him, either in the act of his crime, or afterwards, as punishment, when he is caught and brought to the bar of justice. At the other end of the spectrum, there are extremists such as my debating partner who maintain that only under threat of death may the target use lethal force against the perpetrator. In contrast, I occupy a middle ground. I hold that the victim is legally obligated to withstand initiatory violence in the gentlest manner possible consistent with the right of self-defense; that if in

repute among philosophers, who generally dismiss the concept quickly as 'primitive' or 'barbaric' and then race on to a discussion of the two other major theories of punishment: deterrence and rehabilitation. But simply to dismiss a concept as 'barbaric' can hardly suffice; after all, it is possible that in this case, the 'barbarians' hit on a concept that was superior to the more modern creeds."

${ }^{8}$ Or is it vice versa? 
the heat of the moment more defensive violence is utilized than is strictly necessary (from a Monday morning quarterbacking point of view), this is the fault of the criminal, not the victim. And if this is done to protect against less than a threat of death, this reasoning still holds true. To apply this reasoning to the issue under contention, the mother may (paraphrase) "justifiably deprive her fetus of his life (not) only if it threatens her life" but for a lesser violation of private property rights such as trespassing in her body against her will.

\section{Person or property}

Next, Wisniewski (155) takes me up on my claim that "offenses against the person are more serious, much more serious, than those against mere property." He is quite right to do so, for as it stands, that claim cannot be defended, at least not without some proviso or other to the effect that other things are equal. For example, in the old west, horse stealing was a hanging offense, for the cowboy's very life hung in the balance based on whether or not he could keep this type of transportation free from thieves. In contrast, a punch in the nose is a far lesser offense. But a horse is property, while a nose is part of the person. However, if the above quote is modified to read "offenses against the person are usually or typically more serious than those against mere property" then it can stand as is. However, in Block (2011B), I said this in my footnote 10: "In the good old days of the early days of settlement in the U.S., stealing a man's horse was punished with the death penalty. But, this was because such a theft was really an attack on his person, not merely his property. For, without his horse, the man would die in this hostile territory." I think that absolves me of this criticism of his.

\section{Thomson's (Thomson, 1986, 1990, 1991) case}

$Y$ wakes up in bed attached with an umbilical cord attaching his kidney to $X . X$, an entirely innocent person, is using $Y$ as a kidney dialysis substitute, thanks to the operation of some renegade doctors. Of this Wisniewski (155) states: "it should first be noted that if it is $Y$ who is causally responsible for having $X$ connected to his body, then there is no way in which $X$ can be considered a trespasser. Thus, in the event of the latter's death via disconnection, $Y$ would have to bear the whole responsibility for it, hence becoming guilty of an instance of lethal aggression." But this assumes the very point at issue. It rejects the view, on the basis of no reason offered, that if $Y$ invited $X$ to partake of the benefits of Y's healthy kidney, that $Y$ could not subsequently withdraw this offer at a later date; that $Y$ is responsible for $X$ 's well-being for the entire rest of $X$ 's life; that an invitation, once given, may never be withdrawn. It is difficult to reconcile this with libertarian theory, or, even, with ordinary common sense.

\section{Timing ${ }^{9}$}

Wisniewski (155) states: "Let us not in any way alter Thomson's original scenario except for one detail: now $X$ can survive by staying attached to $Y$ for just one minute. Does this lightly modified scenario suggest that disconnecting $X$ within this short period of time count as an unacceptable violation of the principle of proportionality? If it does, then it would seem that the validity of this principle is purely a matter of contextual judgment, a conclusion I think both of us would wish to avoid."

This is not a very powerful counter argument in that it is undermined by the legal concept of "de minimus": the law cannot and may not take into account trifles. If proper law could incorporate very minor harms, then we would all be prohibited from exhaling, for when we breathe out, we contaminate the atmosphere with carbon dioxide. $Y e s$, it is a gigantic infringement upon liberty to $Y$ to have $X$ attached to his kidneys. But, surely, if it would save X's life to remain attached for a mere one more minute, presumably giving non-criminal doctors time to detach $X$ from $Y$ without undue harm to the former, then it would be improper for $\mathrm{Y}$ to short circuit this procedure by taking a knife and severing the connection right now, instead of waiting a mere 60 seconds, and thus killing the innocent X. So, I will "concede" to Wisniewski if the difference of one minute, or, even, hey, I'll be generous, a few short minutes would spell the difference between the fetus' life, then the mother

9 Tick a tick a tock you need good timing. 
would be legally obligated to wait those few moments before eviction. ${ }^{10}$

But what does this author want to do with this counter example? He wants to run this for the entire nine months. It is my contention that the difference between a few minutes and three quarters of a year is so gigantic that we might as well be talking about different kinds of things, instead of one single concept, time. Let me try to turn back this example on Wisniewski. Is he saying that Thomson's $Y$ is obligated to allow the kidney deficient $X$ stay attached to him for nine months? And why, pray tell, only for this period of time? Why not nine or ninety years for that matter, if this is necessary to preserve X's life? Wisniewski cannot have it both ways. If he insists that the mother may not evict (when it would lead to the baby's death) for nine months, then he must draw the same conclusion about $X$, who is equally innocent, and equally needy. Or, suppose that pregnancy took nine or ninety years? Would Wisniewski's view on evictionism change? I do not at all propose to allow $Y$ to "dismantle (his umbilical cord connection to $\mathrm{X}$ ) in the most immediate and straightforward manner." My vision of proper libertarian law is perfectly willing to force $Y$ to hold off for a very short time, even a few hours or so, if by so doing X's life can be preserved. Similarly, in the eviction of the fetus, it seems not unreasonable to defer the timing for a day or so, if that is the difference between killing and not killing this young human being. But de minimus cannot possibly be stretched to nine months without obliterating the very concept.

\section{Aggressor}

According to Wisniewski (156, fn. 2) "... a fetus cannot be regarded as an aggressor, since aggression presupposes intention; earth quakes, hurricanes, and meteorites cannot be meaningfully thought of as aggressing against us." Certainly, neither the fetus nor (an entirely innocent) $X$ can be regarded as an aggressor. This philosopher is absolutely correct in this contention. Both lack mens rea. Neither can be considered as a criminal. But, it cannot be denied that objectively they are trespassers, a very

10 Is this a positive obligation, contrary to libertarian theory? For an argument in another different matter indeed. They are innocent trespassers; but they are still trespassers.

\section{Concession}

Wisniewski (155-156) concedes to my side of the argument that there is only an "imperfect duty" for the mother to keep the fetus for nine months (and implicitly for $Y$ to keep $X$ attached); he avers she may evict it at any time during her pregnancy, even if this action causes the death of the baby, without being considered a criminal. But this (156, fn. 3) 'concession' does not at all apply to the fetuses brought into existence as a result of consensual intercourse." I appreciate Wisniewski's move in what I consider the correct direction, but it suffers from several flaws.

First, it does not apply to the products of consensual intercourse. But all babies are equally innocent, whether conceived in rape or not. They all have exactly the same amount of mens rea, namely, none at all. Thus this concession of Wisniewski's is illogical. It is incompatible with his pro-life stance. He is condemning a perfectly innocent human being, the product of coercive sexual intercourse, to death, when with just a few months of suffering, this life could be preserved.

Second, my debating partner does not go far enough. There are other cases of non-rape children where the mother did not "invite" in a fetus. She might have been ignorant of the laws of biology, which maintain there is a chance that children are brought about not by the stork, but through sex.

Third, why this gigantic distinction between rape and voluntary sexual intercourse where the mother full well knows of the possibility of pregnancy? Why she is not allowed to change her mind about this (possible) "invitation." It is hardly an invitation if it is only probable that there will later become a person to take advantage of it. Certainly, at the time of the sexual relations (ignoring the father), there was no person in existence who could be invited into her body. According to the laws of biology at least as I am aware of them, the formation of the baby, the fertilized egg, does not occur until some hours

context that it would not be, see Block, 2004B, 2008 
later. $Y$ can invite $X$ to share $Y$ 's kidney. The mother, logically, cannot invite a small person into her body via intercourse, because at that time there was no one to invite. An invitation logically implies two people: an inviter, and an invitee. In Thompson's kidney case, both exist at the time of the invitation. In the case of voluntary intercourse, this requirement is not fulfilled. This concession is thus at once too much and too little. Too much insofar as it contradicts his underlying pro-life position by throwing some innocent fetuses overboard to the wolves, and too little in that it errs in its interpretation of invitations; they are not forever nor for nine months and can be rescinded at will.

\section{Mother versus fetus}

This issue arises when the only way to save the mother's life is to evict the fetus from her bodily premises, but the latter is too young and underdeveloped to survive on his own. Wisniewski comes down on the side of the mother, which is of course consistent with my evictionist position. However, his reasoning is very much incompatible with the libertarian philosophy, at least the way I understand it. For him (157), “... the property rights of the mother have to be weighed against the property rights of the fetus according to the principle of proportionality." First, proportionality only applies to punishment, not defense. Second, this implies that rights can clash, and when they do, there must be a "weighing" of the one against the other. This is a serious misconstrual of libertarianism, in that one of its basic premises is that rights cannot clash (Machan, 2010). When it seems as if there is such an incompatibility, it is necessarily the case that one (or possibly both) of these so-called "rights" is mis-specified. In the present case, it is easy to see which "right" can be no such thing. It is the "right" of the very young human being to perch inside the body of the mother against her will. It is her body that houses him, not the other way around. She, not he, has the right in this case. Nor can the "principle of proportionality" be of any help in our present deliberations. This principle concerns itself with punishment for a crime. But there is no crime in the present circumstances. The lives of the mother and her infant son cannot both be saved. One of them must die. "Proportionality" does not enter the picture in any manner, shape or form. Previously, in Block (2011B) I described Wisniewski's views (157) as being "perilously close to adopting the view that rights can clash." In view of his latest contribution to our joint effort to shed libertarian light on this very contentious issue, I must amend my assessment. Wisniewski's views are the very paradigm case of the erroneous view that rights can clash.

Note, further, that I am not at all concerned with (157) "whether an act of expulsion is morally warranted." As stated above, we are not debating the morality of these issues. If we were, my instincts (I call them no more than that) would be on the side of the fetus, not the mother. To me, there is nothing more heroic than when the mother fowl lays over her brood during the forest fire, saving their lives at the cost of her own. This is highly moral, in my (alas very imperfect) understanding of that concept. And this transcends species. So when the mother gives up her life so that her child can live, this reaches the apogee of morality. But, I digress. As stated above, my contention with Wisniewski has nothing at all to do with morality. It solely concerns the law, and the libertarian analysis of the pro-life and prochoice positions, finding them both seriously wanting.

\section{Justifiable homicide}

States our author (157), “... a simple recognition that $Y$ can justifiably deprive $X$ of his life only if $X$ threatens Y's life." Several counter examples immediately leap to mind. Capital punishment would go by the boards under Wisniewski's conception of libertarianism. If the criminal threatens only serious bodily injury the victim would not be able to engage in deadly force. This bow in the direction of pacifism does not seem to be consonant with libertarian's more Draconian ${ }^{11}$ way of dealing with uncivilized people. It would appear, here, that the tail is wagging the dog. Wisniewski is so intent upon not allowing the

11 See on this Block, 2009A, 2009B; Kinsella, 1996, 1997; Olson, 1979; Rothbard, 1977, 1998; Whitehead and Block, 2003 
pregnant mother to evict a trespasser that he seems willing to bend the libertarian philosophy into contortions to gain this end. I applaud Wisniewski's stance in favor of human life, but am not at all willing to jettison the private property rights of the mother, and the freedom philosophy that supports them, to this end. Nor is this "antilife." For, surely, the best way to promote human life and well-being is by supporting these private property right and libertarian perspectives, not undermining them.

\section{Dragging, danger}

Wisniewski next reprises our recurring argument over whether dragging someone into danger, such as onto an airplane, and then forcing him out (which would certainly violate libertarian law) is akin to a mother "dragging" her baby into her womb (by engaging in sexual intercourse) and then evicting it to its death. I (Block, 2011B) claimed a disanalogy on the ground that the mother did not forcibly "drag" the baby from some safe area and place it in a dangerous one, but, rather, created (with a little help) him right there inside of her. In Wisniewski's latest reply, he makes several errors on this issue.

First he states (157): “...I regard it as incorrect to assert that the mere act of dragging $Y$ on board the plane puts him in danger." Dragging an unconscious person onto a plane (except when you are rescuing him) is an act of kidnapping. The issue is not whether this endangers the victim, but whether or not it is legal under libertarian law. Clearly, it is not. Of course, planes are not per se dangerous vehicles. But the two-fold act of dragging an unconscious (but relatively safely situated) person onto one, and then throwing him out while airborne, certainly is dangerous, not to mention illegal, as it now couples two rights violations: the initial kidnapping, and then murder.

Second, my debating partner (158) “... fail(s) to see the moral relevance of the fact that the fetus was created in the womb rather that forcibly placed there." But, again, we are not concerned with the morality of these acts, rather with their

12 For a libertarian analysis of forcing people to drop to their death see Block, 2003. legal status. Not everything that is immoral should be prohibited by law.

Third, he poses a very tough, but ultimately fallacious, challenge to my position. He opines (158): "Let us modify our airline example and image that, rather than being unconsciously dragged onboard the plane by $\mathrm{X}, \mathrm{Y}$ was biologically engineered by $X$ in his flying laboratory and then ordered to jump out. Would $X$ be any more justified in ordering $Y$ out of his property in such a situation? If Block thinks he would, I fail to see why." I will, again, concede to Wisniewski that this is highly immoral. To biologically engineer a person (think of an adult Frankenstein, but a nice non-aggressing one) and then order him to drop to his death ${ }^{12}$ is the height of immorality. However, we are not now discussing ethics, we are trying to make sense of what the law should be. As a libertarian, we must ask, must we not, who owns the airplane? Wisniewski and I both agree that it is $\mathrm{X}$, the creator of $\mathrm{Y}$, who is the rightful owner of the plane (by analogy, the kidney). If this author wishes to reject libertarianism, well and good. Then, he is free to maintain his pro-life beliefs. But it is not clear how he can do so while still cleaving to the freedom philosophy, based on private property rights.

This author's pot shot at libertarianism is subject to yet another obstacle; the owner of the property is obligated to evict the trespasser in the gentlest manner possible (Block, 2011C). If someone inadvertently steps on your lawn, you are not at all entitled to blow him away forthwith with a bazooka. You are obligated, instead, to inform him that you object to his trespass, and ask him, even politely, if he would withdraw. It is only if he refuses, and then becomes belligerent, that you may properly escalate the level of force you are employing to protect your private property rights. Where does this get us in the case of Frankenstein in the airplane? Well, the gentlest manner possible is hardly a forced removal at 40,000 feet. Much better, and required by libertarian law, would be to land him if at all possible, and then take off again. If the Frankenstein is too young to survive on his own, away from the womb-like environment of the airplane (to get us back to the point at issue), then 
and only then is it legally permissible to protect your private property rights and act in a manner such that he dies.

Although strictly speaking irrelevant, it is good, as the ethicists that Wisniewski seemingly wants libertarians to become, to reflect on the fact that at present, under present pro-choice regulations, millions of babies are slaughtered each year. Under evictionism, fully one third, all of those in their third trimester, when they are viable outside the womb, would be saved. And, as medical technology improves, more and more of them would be saved. Is it really moral on Wisniewski's part to reject this viewpoint, when the alternative is the status quo, not his own pro-life position? I really cannot say for sure, since I am not fully acquainted with the requirements of morality, but I suspect not. (Wisniewski's reasons for rejecting evictionism may be correct, but this is separate from whether or not it is the ethical stance to articulate.)

\section{Railroad track, lake}

We posit that $B$ will be hit by a train, and killed. A pushes her off the track, but into a lake, where $B$ drowns (A cannot swim, is unable to further save her). My position on this scenario is that $A$ is a hero. He preserved B's life by a few minutes. Not only is every life precious, but every moment of every life is also. Wisniewski demurs. He (158) avers: "If A did not push B off the track, anticipating that he is unable to calculate the force of the push so as to avoid throwing $B$ into the lake, then $A$ would clearly be blameless according to the libertarian ethic." I have no idea of what the libertarian ethic is, so I cannot comment on whether or not our author is correct in this contention of his. ${ }^{13}$ Let us, instead, look at this matter from the perspective of libertarian law. Under this latter scenario, A would not be in violation of libertarian law since there are no positive obligations in that legal perspective. A can stand idly by, even though he has it in his power to extend B's life, albeit it only for a few minutes. But what of the initial scenario. Is $\mathrm{A}$ a

13 Again with ethics and morality; perhaps Wisniewski and I really have no differences regarding libertarian law (my sole interest in this debate) but are speaking at cross purposes, since murderer? Has he violated libertarian law? No more than the mother who creates her baby, and gives it only a few minutes of life before evicting it.

Wisniewski attempts to deflect a reductio ad absurdum of mine against what he takes to be his position. I argued that if $\mathrm{J}$ fed a helpless $\mathrm{K}$ for a few days, there is no requirement that $\mathrm{J}$ continue to do so forever. But if $\mathrm{J}$ stops, he does expose $\mathrm{K}$ to a "lethal hazard," namely starvation. Wisniewski objects on the ground that since $\mathrm{J}$ didn't steal K's food, nor prevent him from foraging for it on his own, there is a disanalogy to the preceding $A-B$ case of the train and the lake. And he is of course correct in this. However, this reductio of mine was an attempt, merely, to counteract the claim that exposing someone to a lethal hazard is necessarily a violation of libertarian law. Well, at least my debating partner is now back to libertarianism, and off of morality.

In the view of Wisniewski (159): “... if one voluntarily initiates the causal chain which leads to someone else ending up on her property, the latter person cannot be considered a trespasser. From this it follows that, barring scenarios of rape, an ex post unwanted fetus is not a trespasser and cannot be evicted to its death if the evictor is to act consistently with the libertarian ethic." ${ }^{14}$ But this means that if someone invites someone else to her property, the latter, the invitee, "cannot be considered a trespasser" even if he outstays his welcome. I find this highly problematic. A woman invites a man to her home for dinner. The meal ends. She hints he should leave. He doesn't take the hint. He feels he has the right to stay on for 9 weeks, 9 months, 9 years, 90 years, since the inviter "voluntarily initiates the causal chain which leads to someone else (the invitee) ending up on her property." It is difficult to reconcile this with the doctrine of private property and libertarianism. Rather, the woman has a right to ask the man to leave whenever she wishes, even if it is in the middle of the meal. Ok, ok, she has to give him some time to get up off the chair, put on his coat, find his car keys, etc. This could take, oh, 9 seconds, maybe 9 minutes, tops. No one can do

he is mired in morality and ethics and I totally eschew it for the purposes of this discussion

${ }_{14}$ Perhaps I should interpret Wisniewski's use of the phrase "libertarian ethic" as "libertarian law." 
anything instantaneously. We are all human beings, with limitations. This is covered under the doctrine of de minimus. But to stretch this invitation to 9 months cannot be considered a valid extension of the law.

\section{Implicit contracts}

Wisniewski (159) says that ignorance of the effects of stabbing someone in chest with a knife could not be excused in law. False. If a two year old baby does this, he would obviously lack mens rea, and could not be found guilty of a crime. However, if the baby did this, and/or shot someone, then his guardian or caretaker should be found guilty of aiding and abetting a crime. Similarly, Wisniewski to the contrary notwithstanding, a person ignorant of the (sometime) effects of intercourse can also "annul responsibility" (159) for pregnancy; such a person would also lack the requisite guilty mind to be considered a criminal (as opposed to a tort feaser).

Wisniewski (159) asks: “... what conscious fetus would prospectively ... agree to any invitation shorter than one necessary for allowing the fetal development required to withstand the conditions of the outer world?" If the choice were total nonexistence, or life for a few weeks (before eviction), it seems to me that most people would choose the latter. When there is life, there is always a chance it will be extended. Where there's a will, there's a way. Seize life. Better alive than dead. But these Rawlsian type hypothetical "agreements" cannot be definitive. They have been subjected to too much withering criticism for that (Nozick, 1974).

According to Wisniewski (159): “... if in the context of implicit contracts the acceptable (i.e., judicially enforceable) range of coffee prices is dictated purely by cultural convention, in the case of fetal development the acceptable minimum time the maternal invitation lasts must be dictated by biological considerations)." I argued that there is an implicit contract that when a diner buys and drinks down a cup of coffee, he cannot afterward be presented with a bill for $\$ 1$ million, unless this is clearly specified beforehand. From this Wisniewski infers that there is an implicit contract, which stems from biology, that the "invitation" afforded a woman to her fetus should be in effect for nine months. Before attempting to demolish this argument, let me first tip my hat in Wisniewski's direction. This is indeed a clever attempt to establish his pro-life position as the libertarian one. However, there are difficulties here. An invitation requires two people: an inviter, and an invitee. In the case of sexual intercourse, abstracting from the host mother contract in behalf of the father, there is only one person, not two; at the time of intercourse, there is only the mother, the inviter. The invitee, the fetus, does not yet exist. Therefore, it is a metaphorical overreach on the part of this author, nothing else, to say that the mother "invited" in the fetus for any time at all, let alone nine months, merely by consenting to intercourse, and knowing of its possible results. The point is, invitations have as their basis consent, or agreement, or purpose. Mere biology, the fact that fetal development requires nine months, boasts none of these elements. This is a nice try to undermine evictionism, but I cannot even begin to see how it succeeds.

Moreover, Wisniewski (160) says of implicit contracts that they "do not require signing or even being understood." The first part is correct. By their very nature, and implicit contract need not be, cannot be, signed. If it was agreed to in writing, it would not be implicit. It would be explicit. But understanding is surely an integral part of any contract, implicit or explicit. A contract is a meeting of the minds. In the explicit variety, their signatures indicate that they have read the terms of the agreement and agreed to them. If it is implicit, then a third party, a court, is making a contrary to factual claim: that if the contract had been made explicit (e.g., for a $\$ 1$ million cup of coffee) then there would have been an agreement. Both parties would have been consenting to the same terms. In setting aside this hypothetical "contract" for a vast amount of money for one coffee, the court would be saying that there most certainly would not have been any such agreement.

\section{Alcohol, rape}

I agree with Wisniewski that if all a man does is "ply" (160) a woman with alcohol until she is drunk, and then takes her to his house, this is not necessarily a kidnapping. It could well be just a friendly act, if he puts her to bed for her own safety since she cannot drive home under that condition and then leaves her strictly alone. But if he also has intercourse with her (I go so far as to say even 
if he is married to her) under these conditions, then he is guilty of rape. I don't go so far as the radical feminists to say that she must give verbal consent to each and every step in the seduction, but she cannot be properly said to give consent to intercourse if she is unconscious or even virtually out of it due to inebriation. Certainly if the man and woman are married and live in the same home, his taking her there can hardly count as kidnapping.

\section{Existence}

I do not see how it can be a non sequitur, let alone a "major" (161) one to assert that Wisniewski's existence demonstrates that he prefers that state of affairs to his own non-existence. Of course, there are suicides who take their own lives due to extreme and unrelenting pain, as I (Block, 2011B) acknowledged, as this author even notes (161) but that does not change my analysis of Wisniewski's decision to stay alive in the slightest. Even such unfortunate people act in a manner not inconsistent with my original claim: their suicide demonstrates that they prefer death to life. Most people do not commit suicide, but either die a natural death or are murdered. From this I can deduce that most people prefer to stay alive. I infer that this applies, also, to fetuses who would, I presume, prefer to be born and stay alive for even a short time, if they could but make any such decision, to not having come into being. Therefore, the mother who evicts a fetus improves his condition compared to the one that would have forever continued had she not taken that step.

\section{Utilitarian considerations}

Yes, I suggested that Wisniewski adopt evictionism even only on utilitarian grounds, if nothing else. Better to be right for inferior reasons than wrong. I am of course a deontologist as this author appreciates. But that does not mean I cannot also be aware of utilitarian considerations pointing in the same direction as a rights-based analysis. Indeed, considerations of each can sometimes help the other. For example, it would not be utilitarian for all the world's people to be murdered by the evil Martians. This gives us a leg up in wrestling with challenges to libertarianism of the sort: "when the Martians threaten they will kill all earthlings unless with undertake anti libertarian act X..." what is to be done? At least we have a strong hint as we begin our deontological analysis. ${ }^{15}$ But Wisniewski is not convinced by the utilitarian case for evictionism either. He maintains (161): "If it was my view that the general public decided to adopt, it would make no difference for all those fetuses that can presently survive outside the mother's womb - they would be saved anyway." He is mistaken here. Yes, all fetuses would be saved under pro-life, not merely (an ever expanding) one third of them under evictionism. However, and this is purely a pragmatic consideration, Wisniewski's pro-life view has been very well publicized; to say that it is well-known would be the understatement of the century. Yet, it has not been adopted. It is very far from being enacted. At least as of 2014, in the west, prochoice is in the strong ascendency. In contrast, apart from a few libertarians, evictionism has never been so much as heard of by the general public. It deserves popularization if for no other reason. But there is another reason: evictionism is a true compromise between the two mainstream positions of pro-life and pro-choice. It is therefore much more likely to be adopted than the extreme position now known and out of favor: Wisniewski's pro-life viewpoint. If this author were truly concerned with saving lives, with morality, he would not be so opposed to evictionism. If he accurately applied libertarian theory to this case, he would not only favor evictionism on utilitarian grounds, he would do so for deontological reasons as well.

\section{REFERENCES}

Block, Walter E.1977. "Toward a Libertarian Theory of Abortion." The Libertarian Forum. Vol. 10, No. 9, September, pp. 6-8; http://www.mises.org/journals/lf/1977/1977_09.pdf

Block, Walter E.1978. "Abortion, Woman and Fetus: Rights in Conflict?" Reason, April, pp. 18-25.

\footnotetext{
${ }^{15} \mathrm{~A}$ little fudging never hurt an argument, as long
} as it is a valid one. See Block 2006. 
Block, Walter E.2001. "Stem Cell Research: The Libertarian Compromise." September 3; http://www.lewrockwell.com/block/block5.html

Block, Walter E. 2003. "The Non-Aggression Axiom of Libertarianism," February 17; http://www.lewrockwell.com/block/block26.html

Block, Walter E.2004A. "Libertarianism, Positive Obligations and Property Abandonment: Children's Rights," International Journal of Social Economics; Vol. 31, No. 3, pp. 275-286; http://www.emeraldinsight.com/Insight/viewContainer.do?containerType=Issue\&containerld=1 8709; http://www.walterblock.com/wp-content/uploads/publications/block-children.pdf

Block, Walter E. 2004B. "Libertarianism, Positive Obligations and Property Abandonment: Children's Rights," International Journal of Social Economics; Vol. 31, No. 3, pp 275-286; http://www.emeraldinsight.com/Insight/viewContainer.do?containerType=Issue\&containerld=1 8709; http://www.walterblock.com/wp-content/uploads/publications/block-children.pdf

Block, Walter E. 2006. "Radical Libertarianism: Applying Libertarian Principles to Dealing with the Unjust Government, Part II" Reason Papers, Vol. 28, Spring, pp. 85-109; http://www.walterblock.com/publications/block_radical-libertarianism-rp.pdf

Block, Walter E. 2008. "Homesteading, ad coelum, owning views and forestalling." The Social Sciences. Vol. 3, No. 2, pp. 96-103; http://www.medwelljournals.com/fulltext/TSS/2008/96-103.pdf; http://medwelljournals.com/new/5/archivedetails. php?id=5\&jid=TSS\&theme=5\&issueno $=12$

Block, Walter. 2009A. "Toward a Libertarian Theory of Guilt and Punishment for the Crime of Statism" in Hulsmann, Jorg Guido and Stephan Kinsella, eds., Property, Freedom and Society: Essays in Honor of Hans-Hermann Hoppe, Auburn, AL: Ludwig von Mises Institute, pp. 137-148; http://mises.org/books/hulsmann-kinsella_property-freedom-society-2009.pdf;

Block, Walter. 2009B. "Libertarian punishment theory: working for, and donating to, the state" Libertarian Papers, Vol. 1; http://libertarianpapers.org/2009/17-libertarian-punishment-theory-working-forand-donating-to-the-state/

Block, Walter E. 2010. "Rejoinder to Wisniewski on Abortion." Libertarian Papers; Vol. 32, No. 2; http://libertarianpapers.org/2010/32-block-rejoinder-to-wisniewski-on-abortion/; http://libertarianpapers.org/articles/2010/lp-2-32.pdf

Block, Walter E. 2011A. "Response to Wisniewski on Abortion, Round Two." Libertarian Papers; Vol. 3 , Article No. 4; http://libertarianpapers.org/2011/4-block-response-to-wisniewski-on-abortionround-two/

Block, Walter E. 2011B. "Response to Wisniewski on Abortion, Round Three." Libertarian Papers, Vol. 3, Art. 37; http://libertarianpapers.org/2011/37-block-response-to-wisniewski-on-abortion/

Block, Walter E. 2011C. "Evictionism is libertarian; departurism is not: critical comment on Parr." Vol. 3, Article 36, Libertarian Papers; http://libertarianpapers.org/2011/36-evictionism-is-libertariandeparturism-is-not-critical-comment-on-parr/

Block, Walter E. 2013, forthcoming. "Rejoinder to Parr on Evictionism and Departurism" Journal of Peace, Prosperity \& Freedom, Vol. 2, pp. 125-138; http://jppfaustralia.weebly.com/currentissue.html;

http://jppfaustralia.weebly.com/uploads/1/4/5/5/14558572/journalpeaceprosperityfreedom_sing le.pdf

Block, Walter E. and Roy Whitehead. 2005. "Compromising the Uncompromisable: A Private Property Rights Approach to Resolving the Abortion Controversy," Appalachian Law Review, 4 (2) 1-45; http://www.walterblock.com/publications/block-whitehead_abortion-2005.pdf;

http://www.walterblock.com/wp-content/uploads/publications/block-whitehead_abortion-

2005.pdf;

https://www.researchgate.net/publication/228125532_Compromising_the_Uncompromisable_

A_Private_Property_Rights_Approach_to_Resolving_the_Abortion_Controversy?ev=prf_pub 
Kinsella, Stephen. 1996. "Punishment and Proportionality: the Estoppel Approach," The Journal of Libertarian Studies, Vol. 12, No. 1, Spring, pp. 51-74; http://www.mises.org/journals/jls/12_1/12_1_3.pdf

Kinsella, Stephan. 1997. "A Libertarian Theory of Punishment and Rights," 30 Loy. L.A. L. Rev. 607-45

Machan, Tibor R. 2010. "Rights May Never Be In Conflict," The Daily Bell. May 31; http://szatyor2693.wordpress.com/2010/05/29/column-on-why-basic-rights-cannot-conflict/; http://www.thedailybell.com/1088/Tibor-Machan-Rights-May-Never-Be-In-Conflict.html

Nozick, Robert. 1974. Anarchy, State and Utopia, New York: Basic Books

Olson, Charles B. 1979. "Law in Anarchy." Libertarian Forum. Vol. XII, No. 6, November-December, p. 4

http://64.233.167.104/u/Mises?q=cache:gFT18_ZusWoJ:www.mises.org/journals/lf/1979/1979 _11-12.pdf+two+teeth+for+a+tooth\&hl=en\&ie=UTF-8

Rothbard, Murray N. 1977. "Punishment and Proportionality." R. E. Barnett and J. Hagel, III (eds.), Assessing the Criminal: Restitution, Retribution, and the Legal Process. Cambridge, MA: Ballinger Publishing Co., pp. 259-270.

Rothbard, Murray N. 1998. The Ethics of Liberty, New York: New York University Press. http://www.mises.org/rothbard/ethics/ethics.asp

Thomson, Judith Jarvis. 1986. Rights, Restitution and Risk, Cambridge: Harvard University Press

Thomson, Judith Jarvis. 1990. The Realm of Rights, Cambridge: Harvard University Press

Thomson, Judith Jarvis. 1991. "Self-Defense." Philosophy and Public Affairs, Vol. 20, No. 4, Autumn, pp. 283-310.

Whitehead, Roy and Walter Block. 2003. "Taking the assets of the criminal to compensate victims of violence: a legal and philosophical approach," Wayne State University Law School Journal of Law in Society Vol. 5, No. 1, Fall, pp.229-254

Wisniewski, Jakub Bozydar. 2010A. "A Critique of Block on Abortion and Child Abandonment." Libertarian Papers Vol. 2, No. 16; http://libertarianpapers.org/2010/16-wisniewski-block-onabortion/

Wisniewski, Jakub Bozydar. 2010B. "Rejoinder to Block's Defense of Evictionism." Libertarian Papers. Vol. 2, Art No. 27; http://libertarianpapers.org/articles/2010/lp-2-37.pdf

Wisniewski, Jakub Bozydar. 2011. "Response to Block on Abortion, Round Three." http://libertarianpapers.org/2011/6-winiewski-response-to-block-on-abortion-round-three/; http://libertarianpapers.org/articles/2011/lp-3-6.pdf

Wisniewski, Jakub Bozydar. 2013. "Abortion, Libertarianism and Evictionism: A Last Word." Libertarian Papers, Vol. 5, No. 1, pp. 153-162; http://libertarianpapers.org/2013/6-wisniewski-abortionlibertarianism-and-evictionism/

Received for publication:

20.05.2014

Accepted for publication:

23.06.2014

\section{How to cite this article?}

Style - APA Sixth Edition:

Block, W. (2014, 07 15). Rejoinder to Wisniewski on evictionism, round four. (Z. Čekerevac, Ed.) FBIM Transactions, 2(2), 1-14. doi:10.12709/fbim.02.02.02.01 
Style - Chicago Fifteenth Edition:

Block, W.E. 2014. "Rejoinder to Wisniewski on evictionism, round four." Edited by Zoran Čekerevac. FBIM Transactions (MESTE) 2 (2): 1-14. doi:10.12709/fbim.02.02.02.01.

Style - GOST Name Sort:

Block W.E Rejoinder to Wisniewski on evictionism, round four [Journal] // FBIM Transactions / ed. Čekerevac Zoran. - Beograd : MESTE, 07 15, 2014. - 2 : Vol. 2. - pp. 1-14.

Style - Harvard Anglia:

Block, W., 2014. Rejoinder to Wisniewski on evictionism, round four. FBIM Transactions, 15 07, 2(2), pp. 1-14.

Style - ISO 690 Numerical Reference:

Rejoinder to Wisniewski on evictionism, round four. Block, W.E. [ed.] Zoran Čekerevac. 2, Beograd : MESTE, 07 15, 2014, FBIM Transactions, Vol. 2, pp. 1-14. 